\section{Footprints on the Sands of Time}

The Story of the House of Livingstone, $1863-1963$. Pp. 7I, illustrated. Edinburgh and London: E. \& S. Livingstone. 1963

To anyone interested in the history of medicine this book will make fascinating reading. It is primarily the story of the great house of Livingstone, now celebrating their centenary. As may well be imagined, however, much of it deals with the development of medicine since 1863 and the epoch-making events in the medical world which offered such wonderful opportunities to that far-seeing and resolute man Edward Livingstone, the founder of the firm. In the year when he first opened his premises and started business as a new and second-hand bookseller, it appears that there were no less than I3I firms listed as booksellers and stationers in Edinburgh; and that of these 32 were also publishers and that 13 maintained circulating libraries. Edinburgh at that time had more bookshops per head of the population $(273,997$, compared with the present total of nearly 476,000 ) than now.

The story contains many details of the life and work of famous pioneers such as Sir Henry Littlejohn, Lord Lister, Sir James Young Simpson, Sophia Jex-Blake, Sir Robert Philip, and others. The two brothers, Edward and Stuart, were quick to recognize the work of such medical geniuses and its relation to their position as publishers; so it was that they transferred their premises to a more suitable locality, and ultimately concentrated entirely on the publication of medical and scientific works.

This is a delightful book, beautifully printed in Monotype Baskerville, easy to read, and altogether fascinating. We recommend it to all those who can appreciate the story of the past in its relation to medicine and the publication of scientific and medical works by one of the leading firms in this country, to whom we offer our sincere congratulations.

\section{Selected Papers}

Sir Harry PlatT, Bt., M.D., M.s., F.R.c.s. Pp. vii + I86, illustrated. Edinburgh and London: E. \& S. Livingstone. 1963. 25 s.

In this volume Sir Harry Platt has collected a large number of articles, addresses, speeches, etc., including some of his own, dated from the days succeeding the first world war up to the present day. He deals with the gradual evolution of modern surgery, especially from the orthopædic standpoint: with the general organization of hospitals, with medical science and education, and with the character and personality of numerous distinguished members of the profession in various countries.

The book provides the reader with a great deal of information in a comparatively short space, information which would be hard to get by looking up all the original papers. There are numerous illustrations, the printing is clear and on good paper, and the whole format of the book is attractive. We congratulate the originator of the selection, and the publishers.

\section{Diseases of the Thyroid}

W. R. Trotter. Pp. 195, illustrated. Oxford: Blackwell Scientific Publications. 1962. 32s. 6d.

There has long been a need for a straightforward succinct account of diseises of the thyroid and this book provides one. Written with lucidity, and a refreshing absence of pontification, it can be confidently recommended to all clinicians.

Clear accounts of normal thyroid anatomy and func을 tion and of iodine metabolism are followed by sections on hyperthyroidism, hypothyroidism and simple goitre $; \overline{\frac{2}{}}$ there are short chapters on special types of goitre, $\mathbb{\Phi}$ infective thyroiditis and thyroid cancer, while appen- 0 dices give the essential facts about radioactive iodines tests, plasma protein-bound iodine, B.M.R. (this isa good example of the author's commonsense) and antithyroid antibodies. There are 208 references and an index.

\section{Medical Disorders in Obstetric Practice}

C. K. Barnes, M.D., F.R.C.P. Pp. 302 with 10 figs. Oxford: Blackwell Scientific Publications. 1962. $42 s$.

The author is Assistant Physician to Queen Charlotte's Hospital and Lecturer at the Institute of Obstetrics and Gynæcology, as well as Physician to Hillingdon Hospital, and so is particularly well qualified to write on this difficult and important subject. He hasproduced an excellent book, summarizing present views clearly and adding a selected reference list at the end of each chapter, while drawing extensively on his owno experience, which has obviously been considerable. $\frac{\text { s }}{5}$ Dr. F. J. V. Jenner contributes a chapter on skin dis-? eases; possibly in a future edition one on psychiag y $\vec{C}$ might be included. Another suggestion is that a shertos section listing those drugs known to carry a risk adverse effects on the foetus might be added though 7 t믕 would be hard to be positive about many at the present time. Otherwise this book covers the whole field (there is even a short section on air travel) and considering itso fairly modest size, contains a very large amount of valuable information.

\section{The Essentials of Plastic Surgery}

E. W. Peet and T. J. S. Patterson. Pp. ix +448, with 387 illustrations. Oxford: Blackwell. 1963응 $84 \mathrm{~s}$.

The writers have set out to produce a book such as they would have wished for at the time they decidedo to specialize in plastic surgery, and they assume readers. will have had instruction in general surgery. As isi usual with books of this kind, there are two parts. TheO first lays down general principles of reconstruction and repair and the second describes their application in the various parts of the body. The work is planned as a supplement to practical training, and at the end of eacho chapter is a brief list of references suitable for further reading. Technical detail is less in evidence than explanation of the purpose and possibilities of the various procedures. Views expressed and treatment 0 advocated represent the beliefs and practice of tho authors, and reflect their experience. Debatable opera- $\omega$ tions which might confuse the reader are absent, and there is nothing which is not of proved value.

The principal impression is of sound views, clearly expressed and beautifully illustrated. Photographs are? small but abundant, and they clearly portray effective + surgery. This is a first-class production, and anyone wanting to learn about plastic surgery would be gladP to have it. 